\title{
Effect of Growth Phase on Stability of Fumarase Activity of Brevibacterium flavum Cells Immobilized with $\kappa$-Carrageenan
}

\author{
Isao TAKatA, Tetsuya Tosa and Ichiro Chibata \\ Department of Biochemistry, Research Laboratory of Applied Biochemistry, \\ Tanabe Seiyaku Co., Ltd., \\ 16-89, Kashima 3-chome, Yodogawa-ku, Osaka 532, Japan
}

Received November 8, 1982

\begin{abstract}
Brevibacterium flavum cells obtained from different growth phases were immobilized with $\kappa$ carrageenan and the stability of the fumarase activity was investigated. The stability of fumarase activity of the immobilized preparation of cells of the stationary growth phase was highest. The highest stability of the immobilized cells seemed to be correlated to the high stability of fumarase activity in free cells of the stationary phase. High rigidity of the cell wall and membrane of B. flavum cells of the stationary phase and firm binding of fumarase protein to the cell membrane were suggested from several lines of evidence obtained on treatment of the cells with lysozyme and detergents or sonication of the cells. Electronmicrographs showed that the cells of the stationary phase retained the original shape after repeated batch reactions. Solubilized fumarase prepared from cells of the stationary phase showed the highest stability. Experiments using the partially purified enzyme strongly suggested the existence of fumarase-stabilizing components in the cells.
\end{abstract}

Recently immobilized enzymes and immobilized microbial cells have become of increased interest as biocatalysts for production of useful chemicals, ${ }^{1,2)}$ and several systems have been applied industrially. ${ }^{3 \text { ) }}$

We succeeded in the industial application of immobilized aminoacylase for production of L-amino acids in $1969,{ }^{4)}$ immobilized Esherichia coli cells having aspartase activity for production of $\mathrm{L}$-aspartic acid in 1973, ${ }^{5}$ ) and immobilized Brevibacterium ammoniagenes cells having fumarase activity for production of L-malic acid in 1974. ${ }^{6}$ )

For further improvement of these immobilization systems, we surveyed a variety of synthetic and natural polymers as matrices for entrapping enzymes and microbial cells. ${ }^{7)}$ Among the polymers tested for immobilization of microbial cells, $\kappa$-carrageenan was selected as the most suitable matrix, which was superior to conventional polyacrylamide in terms of the activity yield and operational stability of the immobilized enzyme of cells. ${ }^{8)}$

Thus we changed the conventional pro- duction process for L-malic acid using cells immobilized with polyacrylamide to this new $\kappa$-carrageenan method in 1977.9,10) Furthermore, in 1978 , the production process for $\mathrm{L}$ aspartic acid was altered from the conventional polyacrylamide method to this new method. ${ }^{11)}$ They both gave satisfactory results in terms of economical feasibility.

One of the important criteria for the industrial application of biocatalysts such as immobilized enzymes and immobilized microbial cells is the operational stability. Thus to clarify factors relating to operational stability of fumarase activity, we investigated in detail the stability of fumarase activity of Brevibacterium flavum cells immobilized with $\kappa$ carrageenan gel. ${ }^{12)}$ As a result we found that $\kappa$-carrageenan in the gel-state stabilizes fumarase activity in the microbial cells, and that cultural conditions for cells influence the stability of fumarase activity of immobilized cells. $^{9 \text { ) }}$

In this paper, we report the relationship between the growth phase and stability of 
fumarase activity of $B$. flavum cells immobilized with $\kappa$-carrageenan.

\section{MATERIALS AND METHODS}

Chemicals and reagents. $\kappa$-Carrageenan was obtained from Sansho Co. Ltd. (Osaka, Japan). Bile extract and cetylpyridinium chloride were obtained from Inolex Pharmaceutical Division, Wilson Pharmaceutical \& Chemical Corporation (Illinois, USA), and Tokyo Kasei Kogyo Co. Ltd. (Tokyo, Japan), respectively. Fumaric acid was obtained from Kawasaki Kasei Kogyo Co. Ltd. (Kanagawa, Japan). Other reagents were purchased from Katayama Chem. Ind. Co. Ltd. (Osaka, Japan).

Culture of Brevibacterium flavum. Unless otherwise stated, B. flavum ATCC 14067 was cultured by the method previously reported. ${ }^{10)}$ Cells of 24,48 and $60 \mathrm{hr}$ old (log, stationary and decline phases, respectively) were used in the experiments described in this paper.

Solubilized enzyme. $10 \mathrm{~g}$ (wet weight) of B. flavum cells was suspended in $40 \mathrm{ml}$ of $0.1 \mathrm{M}$ sodium phosphate buffer (pH 7.0) and homogenized at $3,000 \mathrm{rev} . / \mathrm{min}$ for $5 \mathrm{~min}$ with a Dyno-mill KDL-type (Willy A, Bachofen Mashinfabric Basel, Switzerland). The cell debris was removed by centrifugation $(12,000 \times g, 30 \mathrm{~min})$, and the supernatant was collected. Fumarase activity and protein concentration of this solubilized enzyme preparation are given in Table I.

Partially purified enzyme. $20 \mathrm{ml}$ of the solubilized enzyme was fractionated with ammonium sulfate. The precipitate between 40 to $70 \%$ saturation with ammonium sulfate was collected by centrifugation and dialysed overnight against $0.01 \mathrm{M}$ sodium phosphate buffer ( $\mathrm{pH}$ 7.0). Fumarase activity and protein concentration of this partially purified enzyme are shown in Table I.

Free cells. To enhance the fumarase activity and to suppress succinic acid formation, intact cells of B. flavum ( $10 \mathrm{~g}$ wet weight) were suspended in $150 \mathrm{ml}$ of $1 \mathrm{M}$ sodium fumarate $(\mathrm{pH} 7.0)$ containing $0.6 \%$ bile extract, and the mixture was incubated at $37^{\circ} \mathrm{C}$ for $24 \mathrm{hr}$. The cells were washed thoroughly with $0.3 \mathrm{M}$ potassium chloride, and then resuspended in $40 \mathrm{ml}$ of $0.1 \mathrm{M}$ sodium phosphate buffer (pH 7.0). Fumarase activity of the free cells is given in Table I.

Immobilized cells. Intact cells were immobilized by the $\kappa$-carrageenan method previously reported. ${ }^{10)}$ To enhance the fumarase activity and to suppress the succinic acid formation, $15 \mathrm{ml}$ of $1 \mathrm{M}$ sodium fumarate ( $\mathrm{pH} 7.0)$ containing $0.6 \%$ bile extract was added to $6.2 \mathrm{~g}$ of the immobilized cells. The mixture was incubated at $37^{\circ} \mathrm{C}$ for $24 \mathrm{hr}$, and then the gels were thoroughly washed with $0.3 \mathrm{M}$ potassium
Table I. Fumarase Activity of Various B. flavum Cell Preparations

\begin{tabular}{cccc}
\hline & \multicolumn{3}{c}{ Fumarase activity } \\
\cline { 2 - 4 } Enzyme preparation & \multicolumn{3}{c}{ Growth phase } \\
\cline { 2 - 4 } & Log & Stationary & Decline \\
\cline { 2 - 4 } & 3.0 & 2.7 & 2.2 \\
$\begin{array}{c}\text { Solubilized enzyme } \\
(\mu \mathrm{mol} / \mathrm{min} / \mathrm{mg} \text { protein })\end{array}$ & $(8.9)^{a}$ & $(7.7)^{a}$ & $(8.3)^{a}$ \\
$\begin{array}{c}\text { Partially purified enzyme } \\
(\mu \mathrm{mol} / \mathrm{min} / \mathrm{mg} \text { protein })\end{array}$ & 7.0 & 5.5 & 5.3 \\
$\begin{array}{c}\text { Free cells } \\
(\mu \mathrm{mol} / \mathrm{min} / \mathrm{mg} \text { solution })\end{array}$ & 29.4 & $(6.9)^{a}$ & $(7.6)^{a}$ \\
$\begin{array}{c}\text { Immobilized cells } \\
(\mu \mathrm{mol} / \mathrm{min} / \mathrm{mg} \text { gel })\end{array}$ & 26.7 & 27.2 & 29.6 \\
\hline
\end{tabular}

a Values in parenthesis show the protein concentration of the enzyme solution $(\mathrm{mg} / \mathrm{ml})$.

chloride. Fumarase activity of the immobilized cells is given in Table I.

Standard assay of fumarase activity. In the cases of solubilized and partially purified enzyme preparations and free cells, fumarase activity was determined as follows. A mixture of $0.1 \mathrm{ml}$ of enzyme solution or cell suspension and $1.9 \mathrm{ml}$ of $1 \mathrm{M}$ sodium fumarate $(\mathrm{pH} 7.0)$ was incubated at $37^{\circ} \mathrm{C}$ for $10 \mathrm{~min}$ with shaking. The reaction was stopped by the addition of $2 \mathrm{ml}$ of $2 \mathrm{~N}$ hydrochloric acid, and the precipitate of the remaining fumaric acid was removed by centrifugation. The L-malic acid formed in the supernatant was determined colorimetrically by the method of Goodman and Stark. ${ }^{13)}$ In the case of immobilized cells, the fumarase activity was determined by the method described in the previous paper. ${ }^{10)}$

Estimation of operational stability in a continuous column reaction. Immobilized B. flavum cells ( $6.2 \mathrm{~g}$ of gels: $1 \mathrm{~g}$ of wet cells) were packed into a column $(17 \times 150 \mathrm{~mm})$, and a solution of $1 \mathrm{M}$ sodium fumarate $(\mathrm{pH} 7.0)$ was charged into the column at a flow rate of $36 \mathrm{ml} / \mathrm{hr}$ giving between 10 and $20 \%$ of the maximum conversion at $37^{\circ} \mathrm{C}$, and L-malic acid in the effluent was measured. The apparent half-life was estimated by assuming exponential decay of enzyme activity versus time.

Estimation of operational stability in a batchwise reaction. Free cells of $B$. flavum $(1.0 \mathrm{~g}$ wet weight) were added to $30 \mathrm{ml}$ of $1 \mathrm{M}$ sodium fumarate $(\mathrm{pH} 7.0)$, and the mixture was incubated at $37^{\circ} \mathrm{C}$ for 30 min with shaking for estimation of fumarase activity. The cells were then maintained at $37^{\circ} \mathrm{C}$ for 7 days without shaking. The cells were collected from the mixture by centrifugation, washed twice with $30 \mathrm{ml}$ of fresh substrate solution, and then used for the enzyme reaction. The above mentioned batchwise enzyme reactions were repeated five times. 


\section{RESULTS AND DISCUSSION}

A number of papers concerning thermal, ${ }^{14 \sim 18)}$ storage $^{6,19)}$ and operational stabilities $^{6,15,18,20 ~ 24)}$ of a target enzyme in immobilized cells have been published. In most of these papers, stability of the enzyme was discussed from the standpoint of the matrix used for its immobilization. But stability of the target enzyme in immobilized whole cells should also be discussed from the standpoint of the microbial cells used for immobilization. Because interaction between the microbial cells and the matrix constitutes an immobilized cell system, both "cell-history," such as growth phase and cultural conditions, of microbial cells and physicochemical properties of the matrix are very important.

In the previous paper, ${ }^{9}$ ) influences of cultural conditions for microbial cells on the operational stability of fumarase activity of immobilized cells were reported.

In the present paper, stability of the target enzyme, fumarase, in the immobilized cells was investigated with special reference to the "growth phase" of B. flavum.

\section{Effect of growth phase on stability of fumarase activity}

At first, B. flavum cells obtained from different growth phases were immobilized with $\kappa$ carrageenan, and the operational stability of their fumarase activities was compared.

\section{Operational stability}

As shown in Fig. 1, B. flavum cells obtained from different growth phases had the same fumarase activity, but the operational stability of cells immobilized with $\kappa$-carraggenan was different. The immobilized preparation of cells of $48 \sim 54 \mathrm{hr}$ culture showed the highest operational stability.

\section{Stability against external factors}

By using cells cultivated for $24 \mathrm{hr}$ (log phase), $48 \mathrm{hr}$ (stationary phase) and $60 \mathrm{hr}$ (decline phase), the stability of fumarase activity against external factors was investigated with

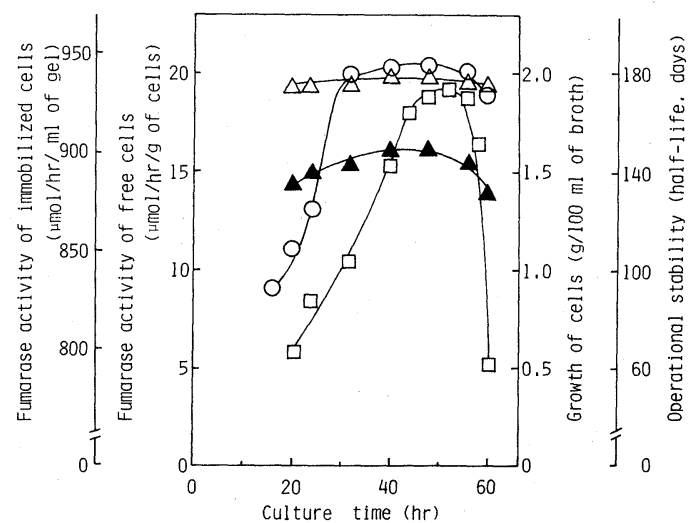

FIG. 1. Effect of Growth Phase on Fumarase Activity and Operational Stability.

B. flavum.was cultivated in $500 \mathrm{ml}$ shaking flasks with $100 \mathrm{ml}$ of medium containing $20 \%$ corn steep liquor, $2 \%$ malonic acid, $0.5 \%$ diammonium citrate, $2.0 \% \mathrm{KH}_{2} \mathrm{PO}_{4}$ and $0.05 \% \mathrm{MgSO}_{4} \cdot 7 \mathrm{H}_{2} \mathrm{O}(\mathrm{pH} 7.0)$ at $30^{\circ} \mathrm{C}$ with shaking (140 rev/min; $8 \mathrm{~cm}$ stroke). $\bigcirc$, growth of cells; $\triangle$, fumarase activity of free cells; $\boldsymbol{\Delta}$, fumarase activity of immobilized cells; $\square$, operational stability at $37^{\circ} \mathrm{C}$.

TABle II. EfFect of Growth Phase on Stabilities of Fumarase ACTIVITy OF FREE CELLS

\begin{tabular}{lccc}
\hline & \multicolumn{3}{c}{$\begin{array}{c}\text { Relative remaining } \\
\text { activity (\%) }\end{array}$} \\
\cline { 2 - 4 } $\begin{array}{c}\text { External factor } \\
\text { (Treating conditions) }\end{array}$ & \multicolumn{3}{c}{ Growth phase } \\
\cline { 2 - 4 } & Log & Stationary & Decline \\
\hline $\begin{array}{c}\text { Heat } \\
\left(55^{\circ} \mathrm{C}, 120 \text { min }\right)\end{array}$ & 5 & 22 & 12 \\
$\begin{array}{c}\text { Organic solvent } \\
(3 \mathrm{M} \text { ethanol, 30 min) }\end{array}$ & 18 & 30 & 5 \\
$\begin{array}{c}\text { Protein denaturing agent } \\
(3 \mathrm{M} \text { urea, 60 min) }\end{array}$ & 37 & 55 & 28 \\
$\begin{array}{c}\text { Repeated use } \\
(\text { After 5th batchwise } \\
\text { reaction) }\end{array}$ & 24 & 75 & 60 \\
\hline
\end{tabular}

a Fumarase activity of a nontreated preparation was taken as $100 \%$.

immobilized and free cell systems and solubilized enzyme.

Thermal stability. As shown in Tables II and III, fumarase activity of cells of the stationary phase was the most thermostable in both free and immobilized systems. Moreover, fumarase activity of cells of every growth phase was 
Table III. EFfect of Growth Phase on Stabilities of Fumarase Activity of IMMOBILIZED Cells

\begin{tabular}{lccc}
\hline & \multicolumn{3}{c}{$\begin{array}{c}\text { Relative remaining } \\
\text { activity }(\%)^{a}\end{array}$} \\
\cline { 2 - 4 } $\begin{array}{c}\text { External factor } \\
\text { (Treating conditions) }\end{array}$ & \multicolumn{3}{c}{ Growth phase } \\
\cline { 2 - 4 } & Log & Stationary & Decline \\
\hline $\begin{array}{c}\text { Heat } \\
\left(55^{\circ} \mathrm{C}, 120 \mathrm{~min}\right)\end{array}$ & 14 & 100 & 24 \\
$\begin{array}{c}\text { Organic solvent } \\
(3 \mathrm{M} \text { ethanol, } 180 \mathrm{~min})\end{array}$ & 100 & 100 & 63 \\
$\begin{array}{c}\text { Protein denaturing agent } \\
(3 \mathrm{M} \text { urea, } 60 \mathrm{~min})\end{array}$ & 63 & 77 & 55 \\
$\begin{array}{c}\text { Repeated use } \\
(\text { After 5th batchwise } \\
\text { reaction) }\end{array}$ & 64 & 100 & 93 \\
\hline
\end{tabular}

a Fumarase activity of a nontreated preparation was taken as $100 \%$.

TABle IV. EfFect of Growth Phase on Stability of Fumarase Activity of Solubilized ENZYMe

\begin{tabular}{|c|c|c|c|}
\hline \multirow{3}{*}{$\begin{array}{c}\text { External factor } \\
\text { (Treating conditions) }\end{array}$} & \multicolumn{3}{|c|}{$\begin{array}{l}\text { Relative remaining } \\
\text { activity }(\%)^{a}\end{array}$} \\
\hline & \multicolumn{3}{|c|}{ Growth phase } \\
\hline & $\log$ & Stationary & Decline \\
\hline $\begin{array}{l}\text { Heat } \\
\qquad\left(45^{\circ} \mathrm{C}, 60 \mathrm{~min}\right)\end{array}$ & 24 & 51 & 36 \\
\hline $\begin{array}{l}\text { Hydrogen ion } \\
\text { concentration } \\
\left(\mathrm{pH} 5.0,37^{\circ} \mathrm{C}, 60 \mathrm{~min}\right)\end{array}$ & 60 & 75 & 70 \\
\hline $\begin{array}{l}\text { Organic solvent } \\
\quad\left(1.5 \mathrm{M} \text { ethanol, } 37^{\circ} \mathrm{C},\right. \\
30 \mathrm{~min})\end{array}$ & 54 & 79 & 73 \\
\hline $\begin{array}{l}\text { Protein denaturing agent } \\
\left(1.5 \mathrm{M} \text { urea, } 37^{\circ} \mathrm{C},\right. \\
2 \mathrm{~min})\end{array}$ & 56 & 89 & 81 \\
\hline
\end{tabular}

a Fumarase activity of a nontreated preparation was taken as $100 \%$.

stabilized as a result of immobilization.

As shown in Table IV, fumarase activity of solubilized enzyme prepared from cells of the stationary phase was most stable, and the stability of the solubilized enzyme prepared from cells from different growth phases was obviously lower than that in intact cells of the

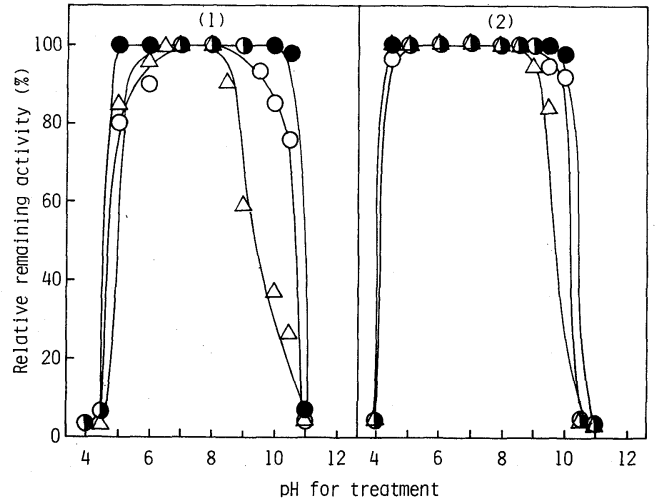

FIG. 2. Effect of Growth Phase on pH Stability of Fumarase Activity.

Free and immobilized cells were maintained in $0.5 \mathrm{M}$ buffer solutions of various $\mathrm{pHs}$ at $37^{\circ} \mathrm{C}$ for $1 \mathrm{hr}$. Buffer solutions used were acetate, $\mathrm{pH} 4.0 \sim 6.0$, phosphate, $\mathrm{pH} 6.0 \sim 7.5$, and borate, $\mathrm{pH} 8.0 \sim 11.0$. Remaining fumarase activity was determined by the method described in the text. (1) free cells; (2) immobilized cells. $\triangle, \log$ phase; stationary phase; $\bigcirc$, decline phase.

corresponding growth phase. These results indicate that the thermal stability of fumarase activity in immobilized cells of the stationary phase would be principally enhanced by $\kappa$ carrageenan gel and binding of fumarase protein to the cell membrane.

$p H$ stability. As shown in Fig. 2, the fumarase activity of free cells of the stationary phase was most stable over a wide $\mathrm{pH}$ range. The $\mathrm{pH}$ stability was enhanced by immobilization, and the immobilized preparation of cells from the stationary phase showed the highest stability at a high $\mathrm{pH}$ region.

In the case of treatment of solubilized enzyme at $\mathrm{pH} 5.0$, the stability of the preparation from cells of the stationary phase was also highest (Table IV). In contrast, the stability of the solubilized enzyme was lower than that of the corresponding cells (Table IV and Fig. 2). From these results, the high $\mathrm{pH}$ stability of the immobilized cell preparation from the stationary phase seemed to be ascribable to the same mechanism as in the case of the thermal stability.

Stability against ethanol and urea. When immobilized cell systems were treated with ethanol and urea, cells of the stationary phase 
exhibited the highest stability, and the reason will be the same as in the cases of thermal stability and $\mathrm{pH}$ stability.

\section{Firmness of cell wall and membrane}

With respect to the two factors influencing the stabilization of fumarase activity of $B$. flavum cells immobilized with $\kappa$-carrageenan, namely physicochemical properties of $\kappa$-carrageenan and cytological differences due to the cell history of B. flavum to be used for immobilization, effects of the former were reported previously. ${ }^{12)}$ This paper deals with a relationship between the cell membrane and the stability in detail.

Relationship between growth phase and extent of cell lysis as well as release of fumarase activity upon lysozyme treatment. To reveal a factor relating to firmness of the structure of the cell wall, cells of different growth phases were treated with lysozyme, and the rate of cell lysis and rate of liberation of fumarase activity were investigated. As shown in Fig. 3, the rate of cell lysis as well as that of release of

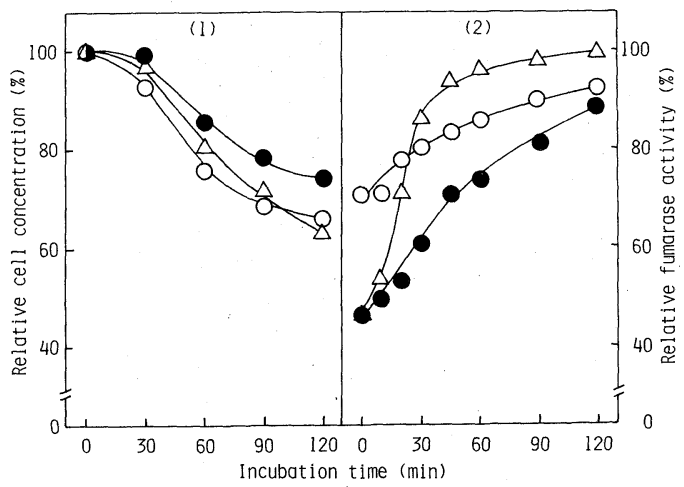

FIG. 3. Relationship between Growth Phase and Celllysis or Liberation of Fumarase Activity upon Lysozyme Treatment of Cells.

$0.1 \mathrm{ml}$ of $5 \%$ lysozyme solution in physiological saline was added to $0.1 \mathrm{ml}$ of a $12.5 \%$ cell suspension in the saline containing $0.01 \mathrm{M}$ sodium phosphate buffer. The mixture was shaken at $37^{\circ} \mathrm{C}$ for an appropriate time, and fumarase activity was estimated with $0.1 \mathrm{ml}$ of the reaction mixture by the method in the text. Another $0.1 \mathrm{ml}$ of the reaction mixture was diluted with $4.9 \mathrm{ml}$ of saline and the cell concentration was estimated from the optical density at $660 \mathrm{~nm}$. (1) cell lysis; (2) fumarase activity. $\triangle, \log$ phase; , stationary phase; $\bigcirc$, decline phase. fumarase activity from cells of the stationary phase was much slower compared with cells of the log and decline phases. The results suggested that the content and/or physicochemical constitution of poly- $\beta$-1,4-acetyl glucosaminide in polysaccharide on the cell wall would be different in each growth phase, and the cell wall of stationary phase cells was found to be most resistant against lysozyme treatment.

Relationship between growth phase and extent of release of fumarase activity upon detergent treatment. To ascertain firmness of the cell wall and membrane, the rate of release of fumarase activity on treatment with detergents, such as cetylpyridinium chloride and bile extract, was investigated. As shown in Fig. 4, fumarase activity of intact cells (corresponding to $0 \%$ detergent concentration) was different in cells obtained from different growth phases and the liberation rate of fumarase activity from cells obtained from the log and stationary phases was almost equal (corresponding to $18 \sim 25 \%$ of the total fumarase activity). On the other hand, that of cells of the

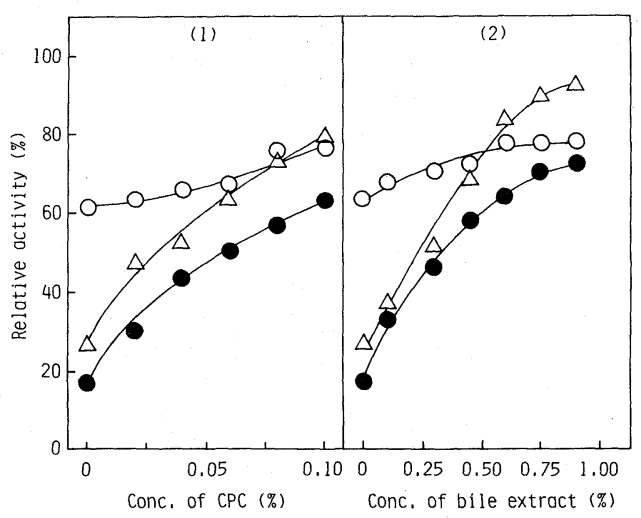

FIG. 4. Relationship between Growth Phase and Liberation of Fumarase Activity upon Detergent Treatment of Cells.

$0.01 \mathrm{ml}$ of bile extract or cetylpyridinium chloride of an appropriate concentration was added to $0.05 \mathrm{ml}$ of a $12.5 \%$ cell suspension in physiological saline containing $0.01 \mathrm{~m}$ sodium phosphate buffer. The mixture was shaken at $37^{\circ} \mathrm{C}$ for $60 \mathrm{~min}$. Fumarase activity was estimated with $0.1 \mathrm{ml}$ of the reaction mixture by the method in the text. (1) cetylpyridinium chloride; (2) bile extract. $\triangle, \log$ phase; $\bigcirc$, stationary phase; $\bigcirc$, decline phase. 
decline phase was $60 \%$ of the total fumarase activity of the cells. These results indicate some alterations in the components and physical structures of the cell membrane during cultivation, especially in the decline phase. When cells of different growth phases were treated with cetylpyridinium chloride or bile extract, the liberation curve of fumarase activity was different between cells of different growth phases. With each concentration of these detergents, the extent of enzyme liberation from cells of the stationary phase was lowest. When cells of the respective growth phases were treated with $0.1 \%$ cetylpyridinium chloride and the treated cells removed by centrifugation, and then fumarase activity of the supernatant was assayed, the enzyme activity released from cells of the $\log$ and decline phases was $20 \%$ of the total activity (data not shown). In contrast, that from cells of the stationary phase was only $5 \%$. From these results, it is suggested that fumarase protein would be associated firmly with the cell membrane in cells of the stationary growth phase.

Relationship between growth phase and liber- ation of fumarase activity upon sonication. To investigate further the firmness of the cell wall and membrane, cells of different growth phases were sonicated and fumarase activity

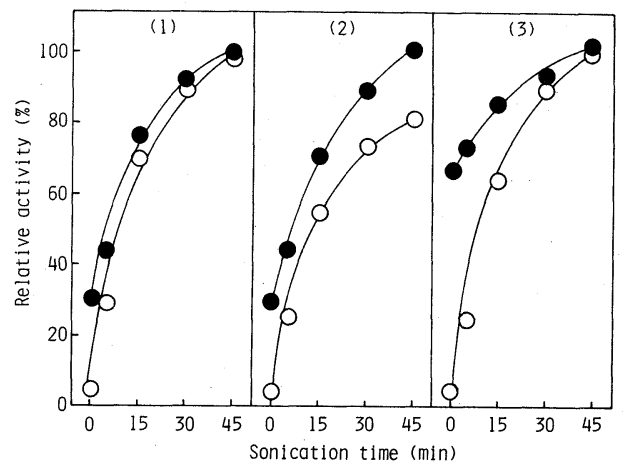

FIG. 5. Relationship between Growth Phase and Liberation of Fumarase Activity upon Sonication of Cells.

$2.5 \mathrm{~g}$ (wet weight) of B. flavum cells was suspended in $10 \mathrm{ml}$ of physiological saline, and the suspension was sonicated with a Kubota Insonator model $200 \mathrm{M}$ at $10 \mathrm{kHz}$ for an appropriate time. Fumarase activity of the sonicated mixture and that of the supernatant centrifuged at $8,000 \times g$ for $30 \mathrm{~min}$ were estimated by the method described in the text. (1) log phase; (2) stationary phase; (3) decline phase. $\bigcirc$, sonicated mixture; $\bigcirc$, supernatant.

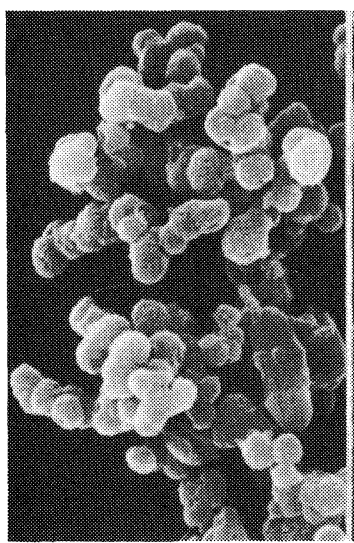

(1)

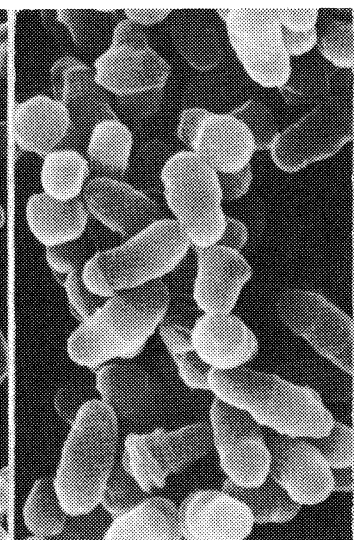

(2)

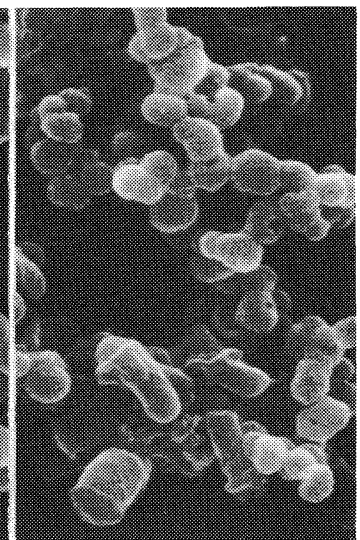

(3)

\section{9रण}

FIG. 6. Scanning Electron Micrographs of Cells Obtained from Different Growth Phases after Batchwise Enzyme Reaction.

Free cells subjected to repeated batchwise enzyme reaction were washed with physiological saline, then subjected to a series of water/ethanol $(50 \sim 80 \%)$ and absolute isoamylacetate, and finally dried at the critical point of carbon dioxide. Resultant specimens were sputter-coated with carbon and successively with gold, and observed with a JSM-35C scanning electron microscope (JEOL Ltd., Tokyo, Japan). (1) log phase; (2) stationary phase; (3) decline phase. 
of the sonicated mixtures and supernatants were compared. The results are shown in Fig. 5. Fumarase activity of cells of the $\log$ and decline phases was almost completely solubilized by sonication for $45 \mathrm{~min}$, whereas $20 \%$ of the total activity remained unsolubilized from stationary-phase cells. Thus, cell walls and membranes obtained at the stationary phase were considered to be the firmest.

Relationship between growth phase and firmness of cell shape. Figure 6 shows scanning electron micrographs of free cells after using for repeated reactions. Cells of the stationary phase retained their original shape, while the shape of cells of the log and decline phases markedly changed.

From these several experiments, fumarase protein in cells of the stationary phase seems likely to be firmly associated with the cell membrane, thus giving the highest stability.

Effect of cellular components on stability of fumarase activity

Some intracellular enzymes are known to be stabilized by cellular components. For example, lipoprotein lipase purified from various sources such as adipose tissue, heart, postheparin plasma and milk has been found to become markedly unstable. On the other hand, heparin, ${ }^{25)}$ fatty acid, ${ }^{26,27)}$ lipid $^{28)}$ and plas$\mathrm{ma}^{26)}$ have been reported to stabilize this enzyme. These facts suggest another mechanism for the high stability of fumarase activity in the immobilized B. flavum cells of the stationary phase, namely the possible contribution of some components which stabilize fumarase protein in situ. If cellular components of $B$. flavum cells contained such stabilizing components and they were removed from the solubilized enzyme, the stability of fumarase activity should change. Table V shows the stability of fumarase preparations from cells of different growth phases, which were partially purified using ammonium sulphate, against external factors. No diffenence was observed in the stability of these three partially purified preparations. On the other
Table V. Effect of Growth Phase on Stability of Fumarase Activity of Partially Purified EnZyme

\begin{tabular}{|c|c|c|c|}
\hline \multirow{3}{*}{$\begin{array}{c}\text { External factor } \\
\text { (Treating conditions) }\end{array}$} & \multicolumn{3}{|c|}{$\begin{array}{l}\text { Relative remaining } \\
\text { activity }(\%)^{a}\end{array}$} \\
\hline & \multicolumn{3}{|c|}{ Growth phase } \\
\hline & $\log$ & Stationary & Decline \\
\hline $\begin{array}{l}\text { Heat } \\
\qquad\left(45^{\circ} \mathrm{C}, 60 \mathrm{~min}\right)\end{array}$ & 23 & 24 & 24 \\
\hline $\begin{array}{l}\text { Hydrogen ion } \\
\text { concentration } \\
\left(\mathrm{pH} 5.0,37^{\circ} \mathrm{C}, 60 \mathrm{~min}\right)\end{array}$ & 45 & 48 & 44 \\
\hline $\begin{array}{l}\text { Organic solvent } \\
\left(1.5 \mathrm{M} \text { ethanol, } 37^{\circ} \mathrm{C}\right. \\
30 \mathrm{~min})\end{array}$ & 23 & 23 & 21 \\
\hline $\begin{array}{l}\text { Protein denaturing agent } \\
\left(1.5 \mathrm{M} \text { urea, } 37^{\circ} \mathrm{C}\right. \\
2 \mathrm{~min})\end{array}$ & 61 & 61 & 60 \\
\hline
\end{tabular}

a Fumarase activity of a nontreated preparation was taken as $100 \%$.

hand, as shown in Table IV, the stability of solubilized enzymes was different against these external factors. Solubilized enzyme prepared from stationary-phase cells showed the highest stability. Even though the protein concentration on treatment for exposure to external denaturing conditions was equal for all preparations of different growth phases, the relative remaining activity of each partially purified enzyme prepared from cells obtained from different growth phases was lower than that of the corresponding solubilized enzyme.

From these results, the preparation of solubilized enzyme prepared from cells of the stationary phase was found to contain more effective compounds for stabilizing fumarase activity or/and to contain compounds making the enzyme unstable at lower concentrations than in preparations of the log and decline phases. This seems likely to indicate another reason for the fumarase activity of preparation immobilized using cells of the stationary phase being most stable.

Thus an immobilized preparation using cells of the stationary phase is considered to be most suitable for industrial purposes. 
Acknowledgments. The authors wish to thank Drs. T. Sato, T. Mori and K. Yamamoto of this laboratory for their helpful discussions on this study. They are also very grateful to Miss K. Kayashima for her assistance.

\section{REFERENCES}

1) I. Chibata and T. Tosa, Adv. Appl. Microbiol., 22, 1 (1977).

2) K. Mosbach, "Methods and Enzymolozy," Vol. 44, ed. by S. P. Colowick and N. O. Kaplan, Academic Press Inc., New York, N. Y., 1976, pp. 3 332.

3) G. M. A. van Beynum, Biotech. Letters, 2, 185 (1980).

4) T. Tosa, T. Mori, N. Fuse and I. Chibata, Enzymologia, 31, 214 (1966).

5) I. Chibata, T. Tosa and T. Sato, Appl. Microbiol., 27, 878 (1974).

6) K. Yamamoto, T. Tosa, K. Yamashita and I. Chibata, Eur. J. Appl. Microbiol., 3, 169 (1976).

7) I. Takata, T. Tosa and I. Chibata, J. Solid-Phase Biochem., 2, 225 (1977).

8) T. Tosa, T. Sato, T. Mori, K. Yamamoto, I. Takata, Y. Nishida and I. Chibata, Biotech. Bioeng., 21, 1697 (1978).

9) I. Takata, K. Yamamoto, T. Tosa and I. Chibata, Eur. J. Appl. Microbiol. Biotech., 7, 161 (1979).

10) I. Takata, K. Yamamoto, T. Tosa and I. Chibata, Enzyme Microb. Technol., 2, 30 (1980).

11) T. Sato, Y. Nishida, T. Tosa and I. Chibata, Biochim. Biophys. Acta, 570, 179 (1979).

12) I. Takata, T. Tosa and I. Chibata, Appl. Biochem. Biotech., 8, 31 (1983).
13) A. E. Goodman and J. B. Stark, Anal. Chem., 29, 283 (1957).

14) R. Couderic and J. Baratti, Biotech. Bioeng., 22, 1155 (1980).

15) K. Yamamoto, T. Tosa and I. Chibata, Biotech. Bioeng., 16, 1589 (1974).

16) S. R. Saif, Y. Tani and K. Ogata, J. Ferment. Technol., 53, 380 (1975).

17) K. Ohmiya, H. Ohashi, T. Kobayashi and S. Shimizu, Appl. Environ. Microbiol., 33, 137 (1977).

18) T. Uchida, T. Watanabe, T. Kato and I. Chibata, Biotech. Bioeng., 20, 255 (1978).

19) T. Hayashi, Y. Tanaka and K. Kawashima, Biotech. Bioeng., 21, 1019 (1979).

20) T. Tosa, T. Sato, T. Mori and I. Chibata, Appl. Microbiol., 27, 886 (1974).

21) K. Yamamoto, T. Sato, T. Tosa and I. Chibata, Biotech. Bioeng., 16, 1601 (1974).

22) T. Tosa, T. Sato, Y. Nishida and I. Chibata, Biochim. Biophys., Acta, 483, 193 (1977).

23) T. Omata, A. Tanaka, T. Yamane and S. Fukui, Eur. J. Appl. Microbiol. Biotech., 6, 207 (1979).

24) K. Sonomoto, A. Tanaka, T. Omata, T. Yamane and S. Fukui, Eur. J. Appl. Microbiol. Biotech., 6, 325 (1979).

25) P. H. Iverius, O. Lindahl, T. Egelrud and $T$. Olivecrona, J. Biol. Chem., 247, 6610 (1972).

26) C. J. Fielding, Biochim. Biophys. Acta, 159, 94 (1968).

27) T. Olivecrona and G. Bengtsson, "Obesity-Cellular and Molecular Aspects," Vol. 87, Inserm, Paris, 1978, p. 125.

28) K. Shimada, J. J. Lanzillo, W. H. Douglas and B. L. Fanburg, Biochim. Biophys. Acta, 710, 117 (1982). 